\title{
Rehabilitacja ruchowa (rehabilitacja przedsionkowa) w zawrotach głowy i zaburzeniach równowagi
}

\section{Motor rehabilitation (vestibular rehabilitation) in dizziness and balance disorders}

\author{
Grażyna Tacikowska ${ }^{1,2}$ \\ ${ }^{1}$ Instytut Fizjologii i Patologii Słuchu, ul. Zgrupowania AK „Kampinos” 1, 01-943 Warszawa \\ ${ }^{2}$ Światowe Centrum Słuchu, ul. Mokra 17, Kajetany, 05-830 Nadarzyn
}

Adres autora: Grażyna Tacikowska, Instytut Fizjologii i Patologii Słuchu, ul. Zgrupowania AK „Kampinos” 1, 01-943 Warszawa, tel: 503711 091, e-mail: g.tacikowska@ifps.org.pl

\begin{abstract}
Streszczenie
Osoby z zaburzeniami narządu przedsionkowego (błędnika) często doznają problemów z utrzymaniem równowagi oraz zawrotów głowy związanych z ruchem lub zmianą położenia głowy. Dolegliwościom tym towarzyszą objawy wtórne związane ze zmniejszeniem aktywności takie jak zmniejszenie siły, utrata zakresu ruchu i zwiększone napięcie mięśniowe (zwłaszcza w rejonie szyi i ramion), co prowadzi do zmęczenia mięśni i bólów głowy. Rehabilitacja przedsionkowa jest specyficzną formą kinezyterapii z udziałem ćwiczeń mających na celu złagodzenie zarówno pierwotnych jak i wtórnych objawów wynikających z zaburzeń narządu przedsionkowego poprzez wzmocnienie kompensacji centralnego układu nerwowego
\end{abstract}

Słowa kluczowe: uszkodzenie narządu przedsionkowego • rehabilitacja ruchowa

\begin{abstract}
People with vestibular disorder often experience problems with balance and position or movement-related dizziness. These primary symptoms are often accompanied by secondary symptoms associated with reduced activity levels. Secondary symptoms include decreased strength, loss of range of motion, and increased tension (particularly in the cervical and shoulder region), leading to muscle fatigue and headaches.
\end{abstract}

Vestibular rehabilitation is a specialized form of therapy involving specific exercises designed to alleviate both primary and secondary symptoms of vestibular disorders by promoting central nervous system compensation.

Key words: vestibular impairment • vestibular rehabilitation

\section{Wstęp}

Pacjenci z uszkodzeniem tak obwodowej jak i centralnej części układu przedsionkowego doznają szeregu podobnych objawów takich jak zawroty głowy typu vertigo, uczucie niepewnej, kołowatej głowy, niewyraźnego widzenia, braku stabilności postawy, chodu a także upadków.

Leczenie pacjentów z deficytem układu przedsionkowego ukierunkowane jest na poprawę funkcji odruchu przedsionkowo-okoruchowego, percepcji ruchu, stabilności posturalnej i ogólnej kondycji fizykalnej. Zaburzony odruch przedsionkowo-oczny interferuje ze zdolnością człowieka do utrzymania stabilnego widzenia podczas ruchów głowy wykonywanych w codziennym życiu. Objawia się to odczuciem zawrotów, niewyraźnym widzeniem czy drganiem widzianego obrazu podczas ruchów głowy. Konflikt sensoryczny powodowany przez nieprawidłową informację z układu przedsionkowego i prawidłową z układu wzrokowego i somatosensorycznego prowadzi do zaburzonej interpretacji ruchu własnego ciała jak i otoczenia [Norre, 1984]. To z kolei generuje niepożądane zachowania takie jak ograniczenie zakresu ruchów głowy a dalej do przykurczu mięśni i bólu.

Prawidłowa postawa ciała wymaga integracji informacji z układu wzrokowego, somatosensorycznego oraz przedsionkowego i następnie prawidłowej odpowiedzi z układu motorycznego. Uszkodzenia narządu przedsionkowego wpływają zarówno na sensoryczną jak i motoryczną część układu równowagi. Pacjenci z uszkodzeniem narządu przedsionkowego mają typowo zaburzenia równowagi wywoływane czy nasilane przez ruch głowy, obroty ciała, czy nagłe zatrzymanie. Aby zachować stabilną postawę, osoby takie rozstawiają stopy (poszerzenie podstawy), redukują 
prędkość chodu, oraz ograniczają ruchy głowy i tułowia. W skrajnych przypadkach używają pomocy w postaci dodatkowego podparcia (np. laski).

\section{Mechanizmy naprawcze i kompensacyjne po uszkodzeniu narządu przedsionkowego}

Organizm „wyposażony” jest fizjologiczne mechanizmy naprawcze i kompensacyjne, które uruchamiają się w przypadku uszkodzenia układu przedsionkowego: spontaniczny mechanizm naprawczy, adaptacja i plastyczność układu przedsionkowego oraz strategie zastępcze $\mathrm{z}$ wykorzystaniem innych układów w celu substytucji układu przedsionkowego [Curthoys, Halmagyi, 1995].

Spontaniczna naprawa polega na wyrównaniu różnicy w aktywności spoczynkowej neuronów układu przedsionkowego (głównie w jądrach przedsionkowych) i ma miejsce zwykle w ciągu kilku dni po uszkodzeniu (dzięki niej na przykład ustępuje objaw ostrego uszkodzenia narządu przedsionkowego jakim jest oczopląs samoistny). Dwa pozostałe mechanizmy natomiast są rozciągnięte w czasie i najbardziej zależą od aktywności fizycznej chorego. Z tego też powodu mechanizmy te wykorzystuje się w rehabilitacji po uszkodzeniach układu przedsionkowego (rehabilitacji przedsionkowej).

Mechanizm adaptacji polega na stopniowej i rozciągniętej w czasie zmianie przedsionkowej odpowiedzi neuronalnej stymulowanej ruchami głowy i bodźcami wzrokowymi. Mechanizm substytucji natomiast polega na większym niż w warunkach normalnych wykorzystaniu odruchów wzrokowo-okulomotorycznych, informacji somatosensorycznej oraz wzrokowej w celu uzupełnienia deficytu informacji przedsionkowej [Herdman, 2001].

\section{Rola ćwiczeń fizykalnych w usprawnianiu pacjenta po uszkodzeniu narządu przedsionkowego}

Wymienione wyżej mechanizmy zaczynają funkcjonować w pełni, jeśli centralny układ nerwowy ma możliwość rozpoznawania nieprawidłowości napływających z obwodu, a to $z$ kolei wywoływane jest ruchem (głowy i ciała). A zatem podstawową zasadą rehabilitacji przedsionkowej jest ekspozycja pacjenta na bodźce (ruchy), które wywołują zawroty i zaburzenia równowagi. Powtarzanie tych ruchów ma za zadanie zniwelować ich właściwości ostrzegające (lęk) oraz w wyniku uczenia się, nabywania, zapamiętywania spowodować powstanie w ośrodkach CUN nowego obrazu - zamiennika poprzedniego, który staje się obrazem akceptowanym [Shamway-Cook, 2008]

Kompleksowe badania Herdman i in. (1995) wykazały, że pacjenci po operacji nerwiaka nerwu słuchowego, którzy wykonywali ćwiczenia adaptacyjne oraz chodu uzyskiwali lepszą stabilność postawy i mniej zaburzeń równowagi niż grupa, która leczona była wyłącznie chodem. Również Krebs i in. (1993), który analizował efekty leczenia u pacjentów z obustronnym uszkodzeniem narządu przedsionkowego ocenił, że pacjenci, którzy wykonywali przedsionkowe ćwiczenia adaptacyjne (np., ruchy głowy z fiksacją wzroku, ćwiczenia ze zmniejszaniem podstawy podparcia $\mathrm{z}$ i bez informacji wzrokowej) uzyskiwali lepszą stabilność niż pacjenci, którzy wykonywali tylko ogólne, niespecyficzne ćwiczenia ruchowe.

\section{Cel rehabilitacji przedsionkowej}

Celem fizykalnych ćwiczeń przedsionkowych jest zmniejszenie odczucia zawrotu przy ruchach głowy, zaburzeń widzenia przy ruchach głowy, poprawa stabilności podczas stania i chodu, zmniejszenia zaburzeń równowagi w warunkach gorszego widzenia lub na nierównej powierzchni oraz zmniejszenie tak zwanej zależności wzrokowej tj pogorszenia się stabilności czy odczucia zawrotu głowy podczas patrzenia na ruchome otoczenie wizualne (np. jadący pociąg).

Zwykle pacjenci badani są na wizycie ambulatoryjnej, gdzie uczą się indywidualnie dobranego zestawu ćwiczeń do dalszej kontynuacji w warunkach domowych. U niektórych pacjentów wprowadzenie do ćwiczeń przedsionkowych odbywa się w warunkach hospitalizacji. Dobre objaśnienie ćwiczeń, ich cel i spodziewany efekty muszą być jasno przedstawione pacjentowi, tak aby czuł on się zmotywowany do samodzielnej, regularnej pracy.

Wiele ćwiczeń stosowanych do poprawy funkcji układu przedsionkowego może początkowo pogorszyć objawy. Istotne jest, aby pacjent miał świadomość, że może czuć się gorzej zanim zacznie czuć się lepiej. Zdarza się, że pogorszenie jest na tyle ostre, ze pacjenci nie chcą kontynuować terapii, w takiej sytuacji konieczna jest modyfikacja ćwiczeń lub ich zaprzestanie i ponowna ocena pacjenta. Zwykle wystarcza zmniejszenie częstości powtórzeń niektórych ćwiczeń i szybkości ich wykonywania.

\section{Badanie pacjenta przed rozpoczęciem rehabilitacji}

Rozpoczęcie terapii za pomocą rehabilitacji przedsionkowej następuje po dokładnej ocenie funkcji narządu przedsionkowego i postawieniu diagnozy lekarskiej w zakresie mechanizmu i przyczyny uszkodzenia narządu przedsionkowego. Istotny jest ogólny stan zdrowa i choroby współistniejące, ponieważ wpływają one min. na dobór ćwiczeń i wyniki rehabilitacji. Na przykład współistniejąca polineuropatia obwodowa czy zaćma będą oddalały i ograniczały procesy kompensacji przedsionkowej.

Po diagnostyce lekarskiej następuje ocena fizjoterapeutyczna. $Z$ reguły jest ona bardzo obszerna (Tabela 1 ), ale nie ma konieczności wykonywania wszystkich jej elementów u każdego pacjenta. Należy dążyć do wykonywania testów, które oceniają wydolność układu równowagi pacjenta w sposób ilościowy. Obiektywizacja możliwości pacjenta jest istotna z punktu widzenia oceny wyników leczenia podczas rehabilitacji.

Ustalenie określonego programu ćwiczeń opiera się na wynikach testów przedsionkowych. Niestety nie zawsze jest możliwość oceny narządu przedsionkowego w pełnym zakresie. Powszechnie wykonywane kliniczne testy przedsionkowe oceniają jedynie kanał półkolisty poziomy, niewiele mamy informacji o funkcji kanałów pionowych i narządu otolitowego, wówczas nasza ocena bardziej opiera na wywiadzie podmiotowym.

$\mathrm{Z}$ drugiej strony nie wszyscy pacjenci z zawrotami głowy mają uszkodzenie narządu przedsionkowego. Jest to istotne, jeśli na rehabilitację trafia pacjent, który nie miał nigdy 
Tabela 1. Ocena pacjenta z zaburzeniami układu przedsionkowego

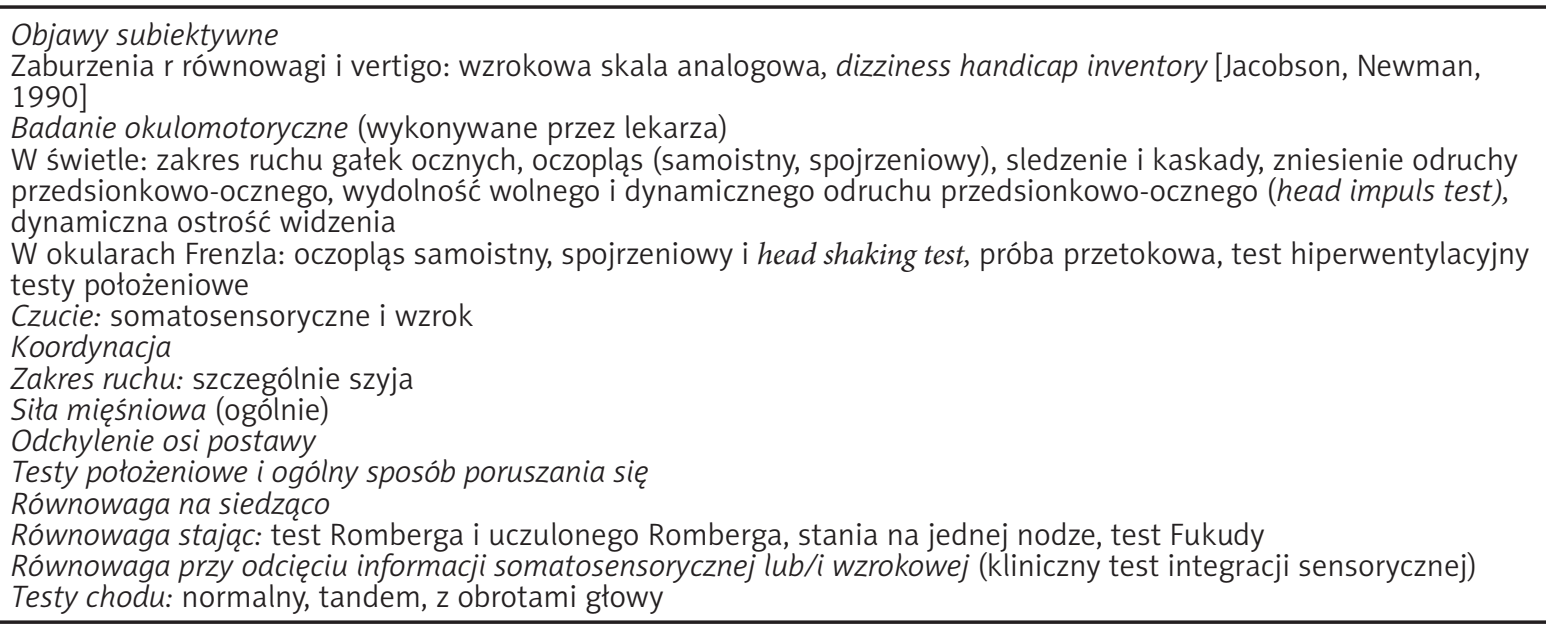

wykonanych testów przedsionkowych. Takie osoby mogą skorzystać z kinezyterapii, aby poprawić ogólną równowagę, ale niekoniecznie potrzebne są im specyficzne ćwiczenia dedykowane poprawie funkcji narządu przedsionkowego. Należy pamiętać, że oczopląs, zawroty głowy i zaburzenia równowagi mogą występować w zaburzeniach pozaprzedsionkowych (działanie leków, uszkodzenie pnia mózgu, móżdżku półkul mózgowych, uszkodzenie układu somatosensorycznego, pozapiramidowego, niskie ciśnienie krwi).

U pacjentów z udokumentowanym uszkodzeniem narządu przedsionkowego istotna jest identyfikacja typu tego uszkodzenia. Czynnościowe testy przedsionkowe pomagają ustalić, czy jest to uszkodzenie obwodowe, czy centralne lub czy jest ono jednostronne czy też obustronne. Zalecane ćwiczenia fizykalne zmieniają się zależnie od typu uszkodzenia. Dla przykładu niektóre ćwiczenia okoruchowe stosowane w obustronnym uszkodzeniu przedsionka jak forsowanie używania ruchów sakkadycznych oczu nie będą właściwe dla pacjentów z jednostronnym uszkodzeniem przedsionka. Nie będą dla nich również stosowne wykonywane w napadowych, położeniowych zawrotach głowy.

\section{Główne zasady i przykłady ćwiczeń stosowanych w rehabilitacji przedsionkowej}

Pacjent powinien ćwiczyć na granicy swoich możliwości. W praktyce oznacza, to że podczas wykonywania ćwiczenia powinien odczuwać zawrót głowy czy niestabilność. Trudność ćwiczenia najłatwiej można regulować poprzez zwiększenie lub zmienianie szybkości jego wykonywania oraz wykonywania w różnych pozycjach i czynnościach (np. obroty głowy w siedzeniu, następnie staniu i w końcu w chodzie) jak również poprzez ograniczenie informacji wzrokowej i/lub somatosensorycznej (np. oczy otwarte-oczy zamknięte) i zmianę warunków otoczenia i kontekstu (np. chód w domu i na otwartej przestrzeni lub w markecie).

Wykorzystanie sygnałów wizualnych i somatosensorycznych musi być zintegrowane z programem ćwiczeń. Oznacza to na przykład, że podczas ćwiczeń poprawiających odruchy posturalne ćwiczenia można wykonywać z zamkniętymi oczami (brak informacji wzrokowej i większe wykorzystanie informacji somtosensorycznej) lub na gąbce (zaburzenia informacji somatosensorycznej i większe wykorzystanie informacji wzrokowej). Tym samym jeśli pacjent ćwiczy na gąbce z oczami zamkniętymi forsowane jest użycie informacji przedsionkowej.

Ćwiczenia składają się sekwencji coraz bardziej złożonych ruchów głowy, zadań wymagających koordynacji oczu z ruchami głowy, ruchów całego ciała i zadań na utrzymanie środka ciężkości. Ćwiczenia sa przeprowadzane w różnych pozycjach, z różną szybkością z oczami otwartymi, zamkniętymi a na końcu w ruchomym i „krzykliwym” otoczeniu wizualnym jak np. centra handlowe.

Ćwiczenia oparte na mechanizmie adaptacji mają zastosowanie u pacjentów $\mathrm{z}$ jednostronnym uszkodzeniem narządu przedsionkowego oraz z częściowym obustronnym. Ich istotą jest poprawa funkcji odruchu przedsionkowo-okoruchowego (stabilizacja oczu podczas ruchów głowy). „Błędnym” sygnałem w tych ćwiczeniach, który jest sygnałem dla mózgu, aby rozpocząć „naprawę” jest ślizganie się obrazu na siatkówce podczas ruchów głowy w przypadku osłabionego odruchu przedsionkowo-okoruchowego. Klasycznym ćwiczeniem adaptacyjnym jest fiksacja wzroku na stabilnym przedmiocie i jednoczesne obracanie głowy (Rycina 1A-C) oraz fiksacja wzroku na przedmiocie który przesuwa się w kierunku przeciwnym do ruchu głowy.

Mechanizm adaptacji odruchu przedsionkowo- okoruchowego jest zależny od kontekstu, dlatego ćwiczenia powinny być wykonywane w różnych warunkach [Collewijn i wsp., 1983], np. z różną częstością ruchów głowy, ponieważ adaptacja układu przedsionkowego jest zależna od częstotliwości pobudzeń narządu przedsionkowego [Goodaux i wsp., 1983]. Jeśli układ zaadoptuje się do danej częstotliwości, odruch przedsionkowo-okoruchowy będzie najbardziej „wydajny” dla tej właśnie częstotliwości.

Ćwiczenia oparte na mechanizmie substytucji mają zastosowanie u osób ze znacznym lub całkowitym obustronnym uszkodzeniem obwodowego narządu przedsionkowego. Ich istotą jest „przetrenowanie” układu równowagi w taki sposób, aby stabilność postawy bardziej zależała od układu wzrokowego i somotosensorycznego niż przedsionkowego. 


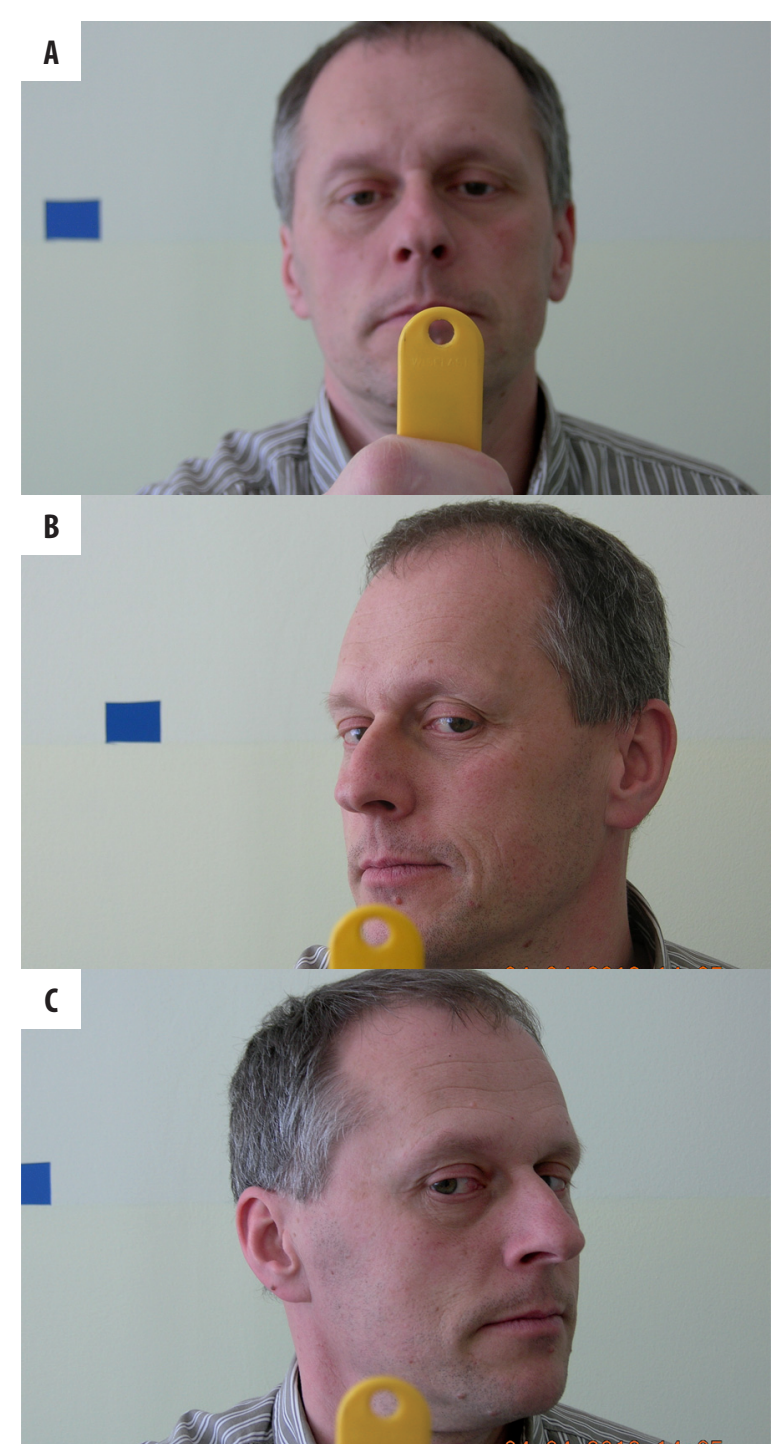

Rycina 1. Podstawowe ćwiczenie w celu poprawy wzmocnienia odruchu przedsionkowo-ocznego. Osoba ćwicząca utrzymując fiksację wzroku na stabilnym celu (A) jednocześnie obraca głowę płynnie w prawo (B) i lewo (C) Ćwiczenie wykonywane jest z fiksacją na małym przedmiocie (widzenie plamkowe) oraz na dużym otoczeniu wizualnym (pełne pole widzenia) w płaszczyźnie horyzontalnej i wertykalnej

Generalna zasada jest taka, że ćwiczenia (głownie chodu) wykonywane są najpierw na twardej powierzchni w pełnym oświetleniu, które następnie jest stopniowo redukowane aż do ćwiczeń z oczami zamkniętymi (wzmocnienie układu somatosensorycznego). Następnie wykonywane są ćwiczenia na miękkiej powierzchni (wzmocnienie układu wzrokowego). Ostatnim etapem są ćwiczenia na miękkiej powierzchni i zniesionym widzeniu lub przy ruchach głowy lub z ruchomym otoczeniem wizualnym (Rycina 2A,B).

\section{Podsumowanie}

Zasadnicze miejsce w leczeniu przewlekłych objawów niewydolności narządu przedsionkowego zajmuje kinezyterapia nazywana tu $\mathrm{w}$ wolnym tłumaczeniu $\mathrm{z}$ języka angielskiego rehabilitacją przedsionkową. Można stwierdzić,
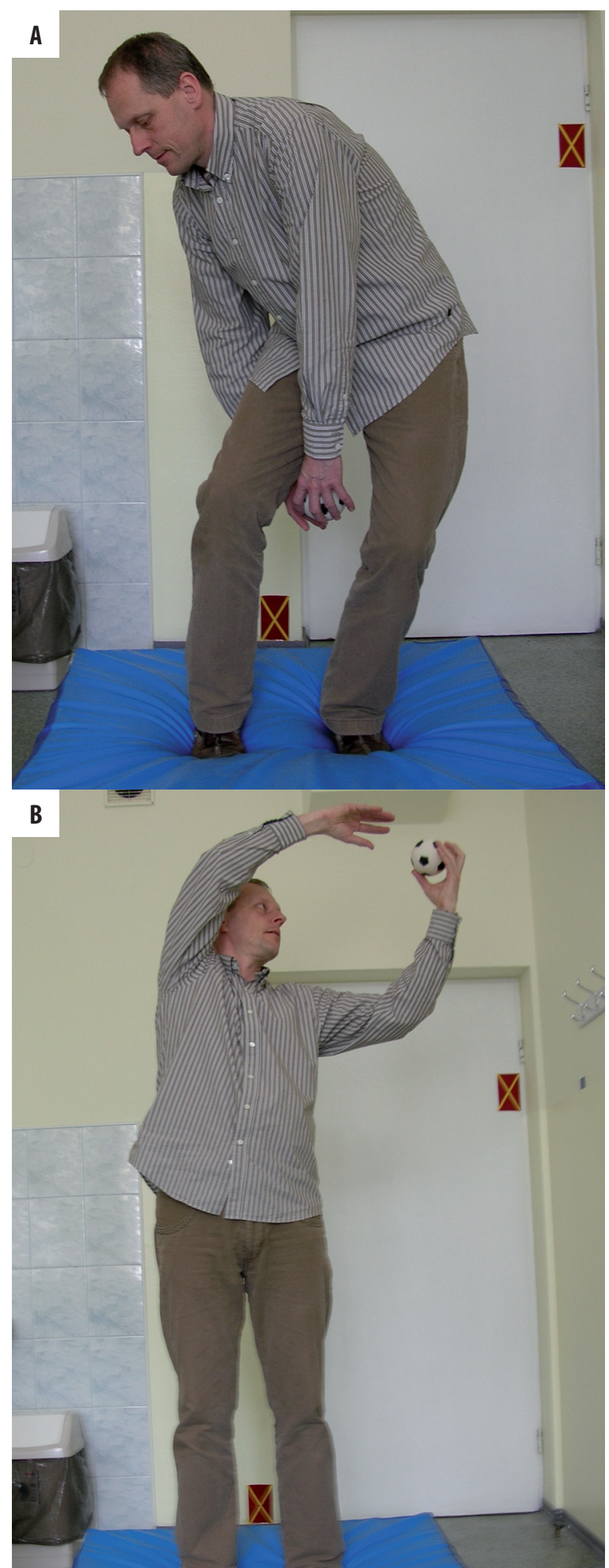

Rycina 2. Osoba ćwicząca stoi na gąbce i jednocześnie przekłada z ręki do ręki małą piłkę na której fiksuje wzrok w pozycji pochylonej (A) oraz nad głową (B)

że wobec braku skutecznego leczenia farmakologicznego i chirurgicznego zawrotów głowy zajmuje ona wiodące miejsce w leczeniu przewlekłym. Znajduje ona gruntowne uzasadnienie $\mathrm{w}$ fizjologii układu równowagi jako całości i w szczególności układu przedsionkowego, a jej zasady porównać można do metody habituacji stosowanej 
w terapii szumów usznych. Rehabilitacja przedsionkowa, rozwijana od lat 40. XX w., swoje źródło znalazła w badaniach, w których obserwowano, że ćwiczenia fizyczne przyspieszają powrót do zdrowia. Początkowo adresowana do pacjentów z przetrwałymi objawami po jednostronnym uszkodzeniu przedsionka do czasu obecnego została zmodyfikowana i poszerzona na inne wskazania. Jest ona stosowana przede wszystkim u pacjentów, którzy nie osiągnęli pełnej kompensacji po ostrym, obwodowym uszkodzeniu narządu przedsionkowego i doznają zawrotu głowy i/lub zaburzeń widzenia podczas ruchów głowy i/lub ciała, u pacjentów po leczeniu destrukcyjnym (np. przecięcie nerwu przedsionkowego), w obustronnych westybulopatiach, w łagodnych napadowych położeniowych zawrotach głowy (zaburzeniach otolitowych), w innych położeniowych zawrotach głowy, w uszkodzeniach układu przedsionkowego na poziomie CUN, w zaburzeniach równowagi w wieku podeszłym.

Jest to program ćwiczeń, których celem jest zmniejszenie wrażenia zawrotu, poprawienie stabilizacji spojrzenia, stabilności postury i ogólnej kondycji fizycznej. Główne grupy ćwiczeń rehabilitacji przedsionkowej to ćwiczenia stabilizujące spojrzenie (przywrócenie funkcji odruchu przedsionkowo-ocznego), ćwiczenia poprawiające kontrolę środka ciężkości (przywrócenie funkcji odruchu przedsionkowo-rdzeniowego), ćwiczenia chodu i ogólne ćwiczenia kondycyjne oraz specyficzne ćwiczenia habituacyjne lub manewry repozycyjne stosowane w łagodnych, napadowych położeniowych zawrotach głowy.

Podstawą dla procedur stosowanych w ramach rehabilitacji przedsionkowej jest znajomość mechanizmów naprawczych po uszkodzeniu przedsionka. Są to adaptacja, tj. dopasowanie się centralnego układu nerwowego do asymetrycznych sygnałów napływających z obwodu, habituacja tj. wygaszanie się reakcji CUN na powtarzany bodziec w aspekcie wywoływanego przez niego nieprzyjemnego odczucia i substytucja, tj. zastępowanie brakującej informacji sensorycznej z jednego układu przez drugi, dobrze funkcjonujący.

Program ćwiczeń z reguły ustalany jest indywidualnie: na podstawie doświadczalnej tj. dobiera się te ćwiczenia, które wywołują objawy oraz na podstawie deficytu stwierdzanego obiektywnie za pomocą badań na wydolność odruchu przedsionkowo-ocznego oraz za pomocą posturografii (najlepiej komputerowej, dynamicznej).

\section{Piśmiennictwo:}

1. Collewijn H., Martins A.J., Stainman R.M.: Compensatory eye movements during active and passive head movements: fast adaptation to changes in visual magnification. J Physiol (London), 1983; 340: 259-86

2. Curthoys IS, Halmagyi GM.: Vestibular compensation: A review of oculomotor, neural and clinical of vestibular loss. J Vestib Res, 1995; 5: 67-108

3. Goodaux E., Halleux J., Gobert C.: Adaptive change of the vestibule ocular reflex in the cat: the effect of a long-term frequency-selective procedure. Exp Brain Res, 1983; 49: 28-29

4. Herdman S.J, Schubert M.C, Tusa R.J.: Role of central preprogramming in dynamic visual acuity with vestibular loss. Arch Otolaryngol Head Neck Surg, 2001; 127(10): 1205-10
5. Herdman S.J., Clendaniel R.A., Mattox D.A. i wsp.: Vestibular adaptation exercises and recovery: acute stage following acoustic neuron resection. Otolaryngol Head Neck Surg, 1993; 113: 71-77

6. Krebs D.E., Gill-Body K.M., Riley P.O., Parker S.W.: Double-blind, placebo controlled trial of rehabilitation for bilateral vestibular hypofunction: preliminary report. Otolaryngol Head Neck Surg, 1993; 109: 735-41

7. Norre ME.: Treatment of unilateral vestibular hypofunction. (W:) Oosterweld W.J. (red). Otoneurology. New York. Wiley, 1984; 23-39

8. Shumway-Cook A.; Veda Publication nr 7, 2008 